\title{
Utilization and turnover of labile dissolved organic matter by bacterial heterotrophs in eastern North Pacific surface waters
}

\author{
Jennifer Cherrier ${ }^{1, *}$, James E. Bauer $^{2}$, Ellen R. M. Druffel ${ }^{3}$ \\ ${ }^{1}$ Department of Oceanography, Florida State University, Tallahassee, Florida 32306, USA \\ ${ }^{2}$ School of Marine Science, College of William and Mary, Gloucester Point, Virginia 23062, USA \\ ${ }^{3}$ Department of Earth Systems Science, University of California Irvine, Irvine, California 92717, USA
}

\begin{abstract}
Seawater incubation experiments were conducted in June and October 1992 to examine bacterial utilization of labile dissolved organic matter (DOM) in open ocean surface waters of the eastern North Pacific. Natural plankton extract-DOM (PE-DOM) and selected model compounds were added to seawater samples to evaluate bacterial utilization and respiration rates relative to bacterial carbon production rates for the various amendments. PE-DOM always stimulated bacterial production and DOM utilization, and the primary nitrogen source supporting this bacterial production was dissolved organic nitrogen (DON). Utilization of DON during exponential growth was balanced by the production of ammonium for samples amended with PE-DOM. Bacterial growth efficiencies for samples amended with PE-DOM ranged between 3.4 and $8.8 \%$ and generally were slightly higher in June than in October. Of the model compounds tested, net bacterial biomass production was observed only in samples amended with glucose, glucose plus ammonium (glucose $+\mathrm{NH}_{4}{ }^{+}$), and dissolved free amino acids (DFAA). Bacterial growth efficiencles for these amendments were $0.8,1.9$, and and $9.3 \%$, respectively. Bacterial production at in situ DOM concentrations was observed in June but not in October. Using the bacterial dissolved organic carbon (DOC) utilization rates observed in this study together with other detailed information pertaining to bulk DOC at our study site, we estimate that the turnover time for labile DOC in these surface waters ranges from approximately 2 to $6 \mathrm{~d}$ depending on the lability of the standing stock of DOC. On the basis of (a) the exclusive use of DON as a nitrogen source in PE-DOM amendments, (b) the stimulation of ammonium utilization in the glucose+ $\mathrm{NH}_{4}{ }^{+}$amendment, and (c) the higher growth efficiencies observed for samples amended with either PE-DOM or DFAA, we suggest that bacterioplankton biomass production in eastern North Pacific surface waters is primarily energy limited. As a result of this energy limitation, bacterial production appears to be additionally constrained by the quality of the nutrients available for assimilation. Thus, the quality of the DOM substrate, specifically the DOC: DON ratio, can be a major determinant of bacterial production in pelagic marine systems.
\end{abstract}

KEY WORDS: Bacterial production - Growth efficiency DOC turnover P Plankton extract-DOM

\section{INTRODUCTION}

Oceanic dissolved organic matter (DOM) represents one of the largest exchangeable reservoirs of organic carbon at the earth's surface (Druffel et al. 1992, Hedges 1992). Phytoplankton production either directly or indirectly supplies DOM to marine systems (via extra-

\footnotetext{
•E-mail: cherrier@ocean.fsu.edu
}

cellular exudation, sloppy feeding by grazers, and particle decomposition), while heterotrophic bacteria, as the primary consumers of DOM, control its remineralization (Azam et al. 1983, Azam \& Ammerman 1984, Kirchman 1990). Determining the factors controlling bacterial remineralization and assimilation of DOM in different marine systems is key to understanding the processes responsible for the persistence of carbon within the oceanic DOM reservoir. Few studies, however, have examined bacterial utilization of bulk DOM in oceanic 
systems (Keys et al. 1935, Rakestraw 1947, Barber 1968, Ogura 1972, Williams \& Carlucci 1976, Kirchman et al. 1991, Carlson \& Ducklow 1995, 1996). This is due in part to the very slow average turnover rates of in situ concentrations of bulk DOM by bacteria as well as to difficulties associated with detection of small changes in the relatively large bulk DOM pool.

To date, rates of DOM uptake and remineralization by bacterial heterotrophs in both pelagic and coastal ecosystems are based largely on turnover times of radiolabeled substrates, uptake of individual model compounds (i.e. glucose, ammonium, or dissolved free amino acids), or uptake of mixtures of model compounds (e.g. Williams \& Carlucci 1976, Sieracki \& Sieburth 1985, Wheeler \& Kirchman 1986, Keil \& Kirchman 1991). While the information gained from these studies has greatly contributed to our understanding of bacterial productivity in different marine environments, uptake rates determined in this manner are indicative of relative, rather than total, bacterial utilization. Additionally, these specific model compounds at best represent only a small fraction of the total pool of utilizable DOM present in natural waters and thus do not allow for extrapolation to bulk DOM (as C or N) fluxes (Burney 1986, Meyers et al. 1987).

Studies employing radiolabeled substrates and model compounds, as well as natural bulk DOM, indicate that bacterial activity in pelagic systems is limited because only a small fraction of the total bulk DOM pool is available for bacterial utilization (Keys et al. 1935, Rakestraw 1947, Barber 1968, Ogura 1972، Williams \& Carlucci 1976). Both the quantity and quality of DOM have been identified as the primary factors affecting its bacterial remineralization and trophic assimilation (Cole et al. 1988, Kirchman 1990, Keil \& Kirchman 1994). Cole et al. (1988) noted that the 'supply or standing stock of organic matter' is the best predictor of bacterial production in the water column. Other studies concur that the concentration of DOM is an important factor in determining bacterial productivity in any given system but add that the quality, specifically the C: N ratio, of the DOM must also be considered when evaluating both the efficiency of utilization and assimilation of bulk DOM (Goldman et al. 1987, Kirchman 1990, Keil \& Kirchman 1991, Coffin et al. 1993, Amon \& Benner 1994). One goal of this research was to evaluate how the quality of both natural and model DOM substrates, as represented by their $\mathrm{C}: \mathrm{N}$ ratios, affects bacterial DOM utilization and growth efficiencies in open ocean environments

Models of organic carbon flux in oceanic surface waters typically balance bacterial production with phytoplankton production (i.e. Fasham 1984, Peterson 1984). However, it is generally recognized that the amount of DOM released by phytoplankton via direct leakage of soluble photosynthate (i.e. $\leq 10 \%$ of primary production) is inadequate to support bacterial carbon consumption which is commonly $>50 \%$ of primary production (Jumars et al. 1989, Pomeroy \& Wiebe 1993). Additional sources of DOM to bacterial heterotrophs include both the products of zooplankton ingestion and digestion and, to a lesser extent, the death and decay of plankton assemblages (Jumars et al. 1989, Pomeroy \& Wiebe 1993). Interestingly, although much emphasis in research has been directed toward understanding microbial food web dynamics, this potentially important zooplankton component has been virtually ignored. Thus, a second goal of this research was to determine if predominantly zooplankton-derived DOM would in fact be utilized by indigenous bacterial populations.

The present study was designed to determine how DOM lability and concentration affect bacterial productivity and DOM turnover in the open ocean. Our first objective was to determine if and to what extent plankton extract-DON (PE-DOM, predominantly zooplankton derived) would be utilized by indigenous bacterial heterotrophs. Our second objective was to compare bacterial DOM utilization and assimilation of both PE-DOM and selected model compounds. We added both the PE-DOM and model compounds such that their respective concentrations would simulate concentrations during an episodic bloom event (i.e. non-steady state conditions). PE-DOM contains a greater range of potentially utilizable substrates normally encountered by bacteria during an episodic bloom event. In contrast, model compounds, at best, represent only a small sub-fraction of those substrates encountered in the bulk DOM pool. It was thus hypothesized that bacterial growth efficiencies would be greater for those samples amended with PE-DOM than for those amended with model compounds. Our results indicate that substrate utilization, respiration, and bacterial growth efficiencies were greatest for those samples amended with labile PE-DOM when compared to the model compounds. Furthermore, the quality of the DOM substrate (i.e. the dissolved organic carbon: dissolved organic nitrogen ratio, DOC:DON) must be considered when predicting rates of bacterial production in open ocean systems.

\section{MATERIALS AND METHODS}

Experimental design. This research was done in conjunction with ongoing investigations of long-term distributions and transformations of DOM in the eastern North Pacific (Bauer et al. in press, Druffel et al. in press). Distribution and transformation patterns of DOM were evaluated by measuring the natural ${ }^{14} \mathrm{C}$ 
abundances of the particulate, colloidal, and dissolved organic pools at various depths within the water column. The sensitivity of this analytical technique to extraneous contamination precluded the use of any radiolabled substrates for the determination of bacterial production rates in the present study. We therefore used changes in bacterial abundances, oxygen consumption, and DOC utilization to estimate bacterial production rates and growth efficiencies.

Experiments were conducted at approximately $34^{\circ}$ $50^{\prime} \mathrm{N}, 123^{\circ} 00^{\prime} \mathrm{W}$ (Stn M) in June and October 1992. The surface waters of Stn M are part of the California Current, and under normal conditions exhibit strong seasonal variabilty in surface water productivity (Michaelson et al. 1988, Smith et al. 1988, K. L. Smith, R. S. Kaufmann \& R. J. Baldwin unpubl.). Maximum surface to deep ocean pariticulate organic carbon fluxes are typically observed between June and July with a secondary maxium between October and November (Smith et al. 1992, unpubl.). However, a major El Niño Southern Oscillation (ENSO) event influenced the region in summer 1992, resulting in lower surface productivity and particle fluxes to the deep water column at Stn M (Smith et al. 1992, unpubl.). Thus, at the time of these experiments, conditions at Stn M may have been more representative of oligotrophic conditions than those during non-ENSO periods.

Eppley et al. (1988) previously observed a deep chlorophyll maximum to be a widespread feature in oligotrophic North Pacific waters and noted that the range of this feature extends from 80 to $150 \mathrm{~m}$ depending on water column stability (i.e. thermal stratification and deep mixing). Using HPLC (high performance liquid chromotography) pigment analysis, it was determined that maximum chlorophyll concentrations occurred at approximately $85 \mathrm{~m}$ at Stn $\mathrm{M}$ in June and October 1992 (T. Bianchi pers. comm.). Since chlorophyll concentrations were high at $85 \mathrm{~m}$, it was initially hypothesized that correspondingly higher bacterial activities would also occur at this depth. Seawater samples were thus routinely collected from $85 \mathrm{~m}$ depth using 12 I Go-Flo bottles.

Seawater from $85 \mathrm{~m}$ was gravity filtered through a precombusted $\left(525^{\circ} \mathrm{C}\right.$ for $4 \mathrm{~h}$ ) GF/F filter (nominal pore size of $\sim 0.7 \mu \mathrm{M})$ to remove particles and bacterial grazers. The filtered water was then distributed into 11 acid-cleaned polycarbonate incubation bottles. Bubbles introduced from this procedure prohibited filtration of water used for oxygen measurements since in situ oxygen concentrations could not be maintained. Therefore, unfiltered water for oxygen measurements was dispensed directly into a series of precombusted $60 \mathrm{ml}$ BOD (biological oxygen demand) bottles (Wheaton, Millville, NJ, USA). Consequently, reported changes in oxygen concentration are potentially conservative estimates of overall 'micro-community' (i.e those organisms $<0.7 \mu \mathrm{m}$ ) respiration rather than bacterial utilization exclusively. The absence of protozoan grazers at all stages in similar experiments conducted in June 1993 (J. Cherrier \& J E. Bauer unpubl.) suggests that their contribution to community respiration was minimal. We did not measure microautotroph abundances and thus do not know the contribution of dark respiration to overall community respiration.

All samples were incubated in the dark at in situ temperatures $\left(13^{\circ} \mathrm{C}\right.$ in June and $11^{\circ} \mathrm{C}$ in October) following the addition of PE-DOM or model compounds. Experimental controls consisted of unamended $85 \mathrm{~m}$ seawater containing ambient in situ concentrations of DOM (June: $72 \mu \mathrm{M} \mathrm{DOC}$ and $4 \mu \mathrm{M}$ DON; October: $69 \mu \mathrm{M}$ DOC and $4 \mu \mathrm{MDON}$ ). All incubations were run in duplicate. Incubation bottles were subsampled at $\leq 3 \mathrm{~d}$ intervals. At all time points bottles were subsampled for DOC, total dissolved nitrogen (TDN), nitrate plus nitrite, ammonium, and bacterial abundances. Changes in oxygen concentration were monitored at each time point by sequentially harvesting replicate $60 \mathrm{ml} \mathrm{BOD}$ bottles that contained DOM concentrations identical to the polycarbonate incubation bottles. Dissolved oxygen was monitored using a YSI Dissolved Oxygen Meter (model 58) equipped with a self stirring BOD Bottle Probe (YSI model 5730). The analytical precision for oxygen measurements was $\pm 2 \mu \mathrm{M}$.

Plankton extract DOM amendments. The DOM used for plankton extract (PE-DOM) amendments was obtained from a zooplankton-dominated plankton assemblage collected from $85 \mathrm{~m}$ depth during a net tow (335 $\mathrm{um}$ net mesh) at the study site in June 1992. To obtain maximum concentrations of DOM, the assemblage was gently heated in a warm water bath (initial temperature $\sim 38^{\circ} \mathrm{C}$ ) for $1 \mathrm{~h}$ and then filtered through a precombusted $\left(525^{\circ} \mathrm{C}\right) \mathrm{GF} / \mathrm{F}$ filter to remove plankton and other particles. The resultant filtrate $(\mathrm{DOC}=32 \mathrm{mM}$, $T D N=7.2 \mathrm{mM}$ ) served as the PE-DOM concentrate which could then be added to incubation bottles in relatively small volumes such that the final concentration would be similar to DOC concentrations observed during episodic bloom events (Kirchman et al. 1991, Biddanda et al. 1994). The PE-DOM was added to separate incubation bottles using an autopipetter to give final DOC concentrations approximately 2 (2x PEDOM) and 3 ( $3 \times$ PE-DOM) times greater than ambient DOC concentrations found at $85 \mathrm{~m}$ depth at the study site. A series of similarly amended BOD bottles accompanied each respective incubation bottle. Plankton extract amendments were carried out in both June and October. Initial DOC and DON concentrations for the plankton extract amendments in June were approximately $128 \mu \mathrm{M} \mathrm{C}$ and $15 \mu \mathrm{M} \mathrm{N}$ for the $2 \times \mathrm{PE}-\mathrm{DOM}$ 
amendment and $175 \mu \mathrm{M} \mathrm{C}$ and $31 \mu \mathrm{M} \mathrm{N}$ for the $3 \times \mathrm{PE}$ DOM amendment. In October, initial starting DOC and DON concentrations for $2 \times$ and $3 \times$ PE-DOM amendments were $120 \mu \mathrm{MC}$ and $17 \mu \mathrm{MN}$, and $162 \mu \mathrm{M} \mathrm{C}$ and $28 \mu \mathrm{M} \mathrm{N}$, respectively.

Model compound amendments. Incubations with model compounds were carried out in October 1992. The compounds added were glucose (Mallinckrodt, Paris, KY, USA), ammonium sulfate (Fisher Scientific, Fair Lawn, NJ), glucose plus ammonium sulfate (Fisher Scientific), urea (Mallinckrodt), potassium phosphate (Baker Chemical Co., Phillipsburg, NJ), and a standard mixture of dissolved free amino acids (DFAA) (Pierce Chemical Co., Rockford, IL, USA). Model compound amendments to incubation and BOD bottles were carried out as described above. The added concentrations of these model compounds were: glucose, $60 \mu \mathrm{M} \mathrm{C}$; ammonium, $10 \mu \mathrm{M} \mathrm{N}$; glucose $+\mathrm{NH}_{4}^{+}, 20 \mu \mathrm{M} \mathrm{C}$ and $10 \mu \mathrm{M} N$ respectively; urea, $15 \mu \mathrm{MN} ; \mathrm{PO}_{4}, 2 \mu \mathrm{M} \mathrm{P}$; and DFAA, $0.500 \mu \mathrm{M}$ DFAA.

Analysis of DOC and DON. All subsamples for DOC and DON analysis were collected in duplicate into precombusted $20 \mathrm{ml}$ scintillation vials with chromic acidwashed Teflon lined caps, and stored at $-20^{\circ} \mathrm{C}$ for subsequent laboratory analysis. DOC and TDN were measured using modifications of the high-temperature $\left(680^{\circ} \mathrm{C}\right)$ flow-through catalytic oxidation methods outlined by Bauer et al. (1993) and Williams et al. (1993). A $100 \mu$ aliquot of an acidified $\left(10 \% \quad \mathrm{H}_{3} \mathrm{PO}_{4}\right.$, final $\mathrm{pH}$ 1.5-2.0), sparged (to remove inorganic carbon) subsample was injected into a high-temperature catalytic oxidation system containing 2 to $3 \% \mathrm{Pt}$ on aluminosilicate (faujasite) catalyst. The resultant carbon dioxide produced from DOC oxidation was detected on a Rosemount Analytical IR detector (model 880). Nitric oxide produced from TDN oxidation was detected using a Thermo Environmental Instruments Inc. model 42 chemiluminescence $\mathrm{NO}-\mathrm{NO}_{2}-\mathrm{NO}_{x}$ analyser. Details of this system are presented by Williams et al. (1993) The system was calibrated using both liquid (glucose for DOC, EDTA, urea, and nitrate for TDN) and gas $\left(\mathrm{CO}_{2}\right.$ for $\mathrm{DOC} ; \mathrm{NO}$ for TDN) standards. All reported DOC and TDN concentrations were corrected by the appropriate system blanks using injections of UV-oxidized Milli-Q water. The analytical error ( \pm 1 standard deviation) for DOC was 4 to $5 \mu \mathrm{M}$ and $0.5 \mu \mathrm{M}$ for TDN

Analyses of nitrate and nitrite were carried out on a $100 \mu$ sample aliquot by vanadium (III) reduction with chemiluminescent detection of $\mathrm{NO}$ as outlined by Garside (1982) and Braman \& Hendrix (1989). Ammonium concentrations were determined by the standard colorometric techniques of Solorzano (1969). DON utilization for each treatment was determined by subtracting the sum of nitrate plus nitrite plus ammonia from the TDN concentrations.
Dissolved iree amino acid analysis. All subsamples for DFAA analysis were prefiltered through $0.2 \mu \mathrm{m}$ polycarbonate filters (Poretics, Livermore, CA, USA) under a sterile hood using a precombusted glass filtration apparatus. The filtrate was collected in duplicate into precombusted glass scintillation vials equipped with acid-washed Teflon lined closures and stored at $-20^{\circ} \mathrm{C}$ for subsequent DFAA analysis. The DFAA were quantified by reverse phase HPLC using modifications of the ophthaldialdehyde (OPA) method outlined by Lindroth \& Mopper (1979), with a buffering system and elution gradient modified from Hill et al. (1979) (Shultz 1994). Samples were analyzed using a Shimadzu HPLC (Shimadzu Instruments, Columbia, MD, USA) system equipped with an LPM 600 pump, RF 535 fluorescence detector, CR 501 integrator, and a $250 \mathrm{~mm}$ Adsorbosphere column (Alltech, Deerfield, IL).

Bacterial enumeration and biomass conversion. Subsamples for bacterial enumeration were collected in duplicate from the polycarbonate incubation bottles and preserved in $4 \%$ filtered $(0.2 \mu \mathrm{m})$ buffered formalin. Samples were stored in the dark at $4^{\circ} \mathrm{C}$ until enumeration. Bacterial abundances were determined by epifluorescence microscopy using modifications $\left(0.1 \mu \mathrm{g} \mathrm{ml}^{-1} \mathrm{DAPI}\right)$ of the 4',6-diamidino-2-phenylindole (DAPI) (Sigma Chemical Co., St. Louis, MO, USA) staining technique of Porter \& Feig (1980). Subsequent control experiments in which samples of varying bacterial abundances were individually stained with different concentrations of DAPI $(0.1,1.0$, and $5.0 \mu \mathrm{g}$ $\mathrm{ml}^{-1}$ ) confirmed that bacterial numbers were not

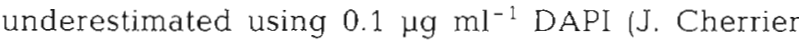
unpubl. data). For each sample, a minimum of 300 bacteria or 20 fields were counted.

The equivalent spherical diameter of the bacteria in our samples $(0.4$ to $0.6 \mu \mathrm{m})$ was similar to that $(0.4$ to $0.5 \mu \mathrm{m})$ used by Lee \& Fuhrman (1987). Thus, we assumed a constant biomass conversion factor for the determination of bacterial carbon biomass. Bacterial carbon biomasses were calculated from bacterial abundances using the biomass conversion factor of $19.6 \mathrm{fg} C$ per bacterial cell reported by Lee \& Fuhrman (1987).

\section{RESULTS}

June 1992

Incubation experiments in June were conducted to (a) estimate bacterial productivity within the chlorophyll maximum at ambient DOM concentrations and (b) determine whether and to what extent bacterial production is stimulated by PE-DOM. DOC and DON utilization, oxygen consumption, and bacterial abun- 
dances were monitored throughout a $2.5 \mathrm{~d}$ period for both experimental samples (i.e. $2 \times$ and $3 \times$ PE-DOM amended seawater) and controls (i.e. unamended 'ambient' seawater) and are shown in Fig. 1. Rates of DOC, DON, and $\mathrm{O}_{2}$ utilization $\left(-\mu \mathrm{M} \mathrm{d}^{-1}\right)$ and bacterial carbon production $\left(+\mu \mathrm{M} \mathrm{d}^{-1}\right)$ and their respective standard errors were determined by least squares linear regression of each parameter against the time of incubation for all data points in duplicate samples (i.e. 0 to $2.5 \mathrm{~d}$; Table 1). In some instances a $24 \mathrm{~h}$ lag period was observed. However, corresponding lag periods were not consistently observed in all measured parameters. For purposes of comparison and consistency between measured parameters, the lag period was not taken into account in the linear regressions. Therefore, estimates of DOC, DON and $\mathrm{O}_{2}$ utilization and bacterial carbon production rates are considered conservative. Although differences between treatments were observed, they were not always significant at the 95\% confidence level.

The greatest rates of DOC $\left(19.2 \pm 3.4 \mu \mathrm{M} \mathrm{C} \mathrm{d}^{-1}\right)$ and $\mathrm{O}_{2}\left(12.4 \pm 3.6 \mu \mathrm{M} \mathrm{O}_{2} \mathrm{~d}^{-1}\right)$ utilization were observed in the $3 \times$ PE-DOM amendment (Fig. 1., Table 1). These rates were almost twice as high as those observed in the $2 \times \mathrm{PE}-\mathrm{DOM}$ amendment $\left(12.3 \pm 2.6 \mu \mathrm{M} \mathrm{C} \mathrm{d}^{-1}\right.$ and $\left.6.5 \pm 0.8 \mu \mathrm{M} \mathrm{O}_{2} \mathrm{~d}^{-1}\right)$. However, the respective DON utilization rates $\left(0.54 \pm 0.7\right.$ and $\left.1.16 \pm 0.7 \mu \mathrm{M} \mathrm{N} \mathrm{d}^{-1}\right)$ and bacterial carbon production rates $(0.30 \pm 0.17$ and 0.66 $\pm 0.14 \mu \mathrm{M} \mathrm{C} \mathrm{d} \mathrm{d}^{-1}$ ) were similar in both treatments. Changes in DON concentrations in PE-DOM amended samples were stoichiometrically matched by ammo-
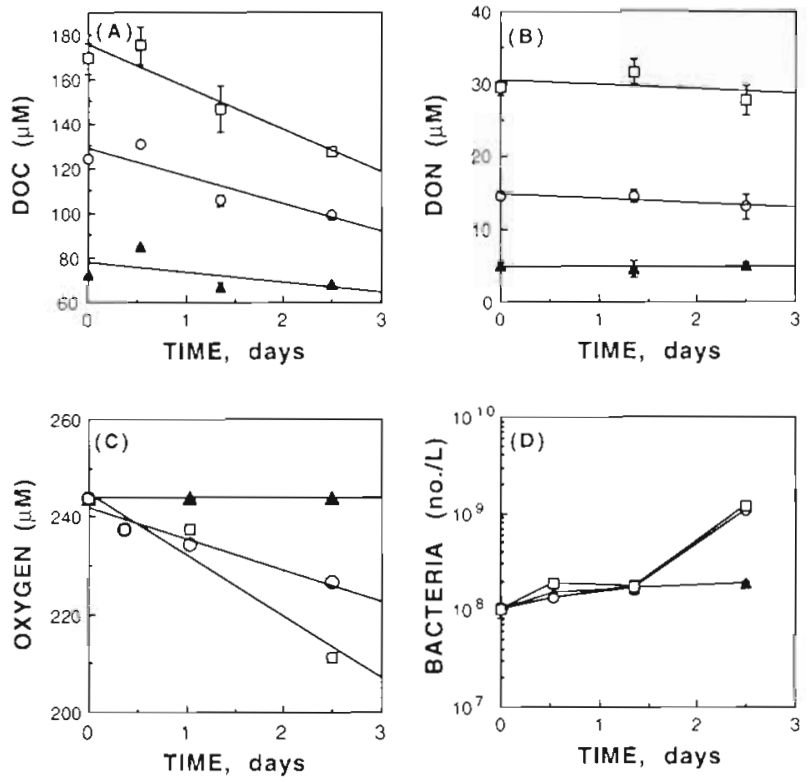

Fig. 1. June 1992. Changes in (A) DOC, (B) DON, (C) oxygen, and (D) bacterial abundances over time for unamended seawater samples (4) and samples amended with plankton extract-DOM (0, $2 \times$ PE-DOM; $\square, 3 \times$ PE-DOM). Error bars represent \pm 1 SD of duplicate samples. Lines for DOC, DON. and $\mathrm{O}_{2}$ utilization were derived using linear regression analysis, see text

nium production (Fig. 2) since no changes in nitrate or nitrite concentrations were detected in any of the treatments throughout the course of the experiment (data not shown). A decrease in DOC $(4.4 \pm 2.6 \mu \mathrm{M} \mathrm{C}$

Table 1. Rates of bacterial carbon production and oxygen, DOC, and DON utilization for incubation expenments conducted at Stn M in June and October 1992 (length of incubation is shown). Rates were calculated by least squares linear regression of each parameter against time for all data points in duplicate incubations (Figs. 1 \& 3). Errors represent \pm 1 SE of rate calculations. ud: undetectable; -: data not collected

\begin{tabular}{|c|c|c|c|c|c|}
\hline Date & Treatment & $\begin{array}{c}\text { Bacterial C } \\
\text { production } \\
\left(\mu \mathrm{M} \mathrm{d}^{-1} \pm 1 \mathrm{SE}\right)\end{array}$ & $\begin{array}{c}\mathrm{O}_{2} \\
\text { utilization } \\
\left(\mu \mathrm{M} \mathrm{d}^{-1} \neq 1 \mathrm{SE}\right)\end{array}$ & $\begin{array}{c}\text { DOC } \\
\text { utilization } \\
\left(\mu \mathrm{M} \mathrm{d}^{-1} \pm 1 \mathrm{SE}\right)\end{array}$ & $\begin{array}{c}\text { DON } \\
\text { utilization } \\
\left(\mu \mathrm{M} \mathrm{d}^{-1} \pm 1 \mathrm{SE}\right)\end{array}$ \\
\hline $\begin{array}{l}\text { Jun } 1992 \\
(0-2.5 \mathrm{~d})\end{array}$ & $\begin{array}{l}\text { Ambient } \\
2 \times \text { PE-DOM } \\
3 \times \text { PE-DOM }\end{array}$ & $\begin{array}{l}0.05 \pm 0.01 \\
0.30 \pm 0.17 \\
0.66 \pm 0.14\end{array}$ & $\begin{array}{c}\text { ud } \\
6.5 \pm 0.8 \\
12.4 \pm 3.6\end{array}$ & $\begin{array}{r}4.4 \pm 2.6 \\
12.3 \pm 2.6 \\
19.2 \pm 3.4\end{array}$ & $\begin{array}{c}u d \\
0.54 \pm 0.7 \\
1.16 \pm 0.7\end{array}$ \\
\hline \multirow[t]{2}{*}{$\begin{array}{l}\text { Oct } 1992 \\
(0-2.8 d)\end{array}$} & $\begin{array}{l}\text { Ambient } \\
2 \times \text { PE-DOM } \\
3 \times \text { PE-DOM }\end{array}$ & $\begin{array}{c}\text { ud } \\
0.20 \pm 0.02 \\
0.42 \pm 0.03\end{array}$ & $\begin{array}{c}\text { ud } \\
5.8 \pm 1.4 \\
11.6 \pm 2.6\end{array}$ & $\begin{array}{r}1.4 \pm 2.0 \\
10.6 \pm 1.4 \\
9.9 \pm 2.8\end{array}$ & $\begin{array}{c}u d \\
1.56 \pm 0.3 \\
2.75 \pm 0.7\end{array}$ \\
\hline & $\begin{array}{l}\text { Ambient } \\
\mathrm{NH}_{4}{ }^{+} \\
\text {Glucose } \\
\text { Glucose }+\mathrm{NH}_{4}{ }^{+} \\
\mathrm{PO}_{4} \\
\text { Urea }\end{array}$ & $\begin{array}{c}\text { ud } \\
\text { ud } \\
0.01 \pm 0.001 \\
0.03 \pm 0.006 \\
\text { ud } \\
\text { ud }\end{array}$ & $\begin{array}{c}\text { ud } \\
\text { ud } \\
1.92 \pm 1.5 \\
1.74 \pm 0.4 \\
\text { ud } \\
\text { ud }\end{array}$ & $\begin{array}{l}\text { ud } \\
\text { ud } \\
2.9 \pm 1.4 \\
6.2 \pm 1.2 \\
\text { ud } \\
\text { ud }\end{array}$ & $\begin{array}{l}\text { ud } \\
\text { ud } \\
\text { ud } \\
\text { ud } \\
\text { ud } \\
\text { ud }\end{array}$ \\
\hline$(0-2.9 \mathrm{~d})$ & $\begin{array}{l}\text { Ambient } \\
\text { DFAA }\end{array}$ & $\begin{array}{c}u d \\
0.01 \pm 0.002\end{array}$ & $\begin{array}{c}\text { ud } \\
-\end{array}$ & $\begin{array}{c}\mathrm{ud} \\
0.12^{\mathrm{d}} \pm 0.02^{\mathrm{d}}\end{array}$ & $\begin{array}{l}\text { ud } \\
\text { ud }\end{array}$ \\
\hline
\end{tabular}


$\left.\mathrm{d}^{-1}\right)$ and an increase in bacterial carbon biomass $(0.05$ $\pm 0.01 \mu \mathrm{M} \mathrm{C} \mathrm{d}^{-1}$ ) were observed in the experimental control, however, no changes in $\mathrm{O}_{2}$ or DON concentrations were detected (Fig. 1, Table 1). Any oxygen consumption or DON utilization that may have occurred in the experimental control was below the sensitivity of our analytical instrumentation.

\section{October 1992}

The primary objective of the October incubation experiments was to evaluate bacterial DOM utilization and assimilation of both PE-DOM and model compounds. In addition to amending samples with natural DOM $(2 \times$ and $3 \times$ PE-DOM), we also supplemented seawater samples with ammonium, glucose, glucose+ $\mathrm{NH}_{4}{ }^{+}$, phosphate, urea, and DFAA. Unamended ambient seawater again served as the experimental control. Changes in DOC, DON, oxygen, and bacterial abundances were monitored over a $2.8 \mathrm{~d}$ incubation period (Fig. 3). DOM utilization, oxygen consumption, and bacterial biomass production rates were calculated in the same manner as described above for the June experiments and are summarized in Table 1. In the case of the DFAA amendment, where the beginning concentration $(0.54 \mu \mathrm{M})$ was below the analytical detection limit for DOC analysis, DOC utilization rates were calculated from changes in DFAA carbon equivalent concentrations over time.

Of the substrates tested, only PE-DOM, glucose, glucose $+\mathrm{NH}_{4}{ }^{+}$, and DFAA stimulated bacterial biomass production (Table 1). The greatest changes in DOC and DON concentrations, oxygen utilization, and bacterial abundances were observed for the $2 \times$ and $3 \times \mathrm{PE}$ DOM amended samples (Fig. 3). Similar to those observed in the June experiments, changes in DON

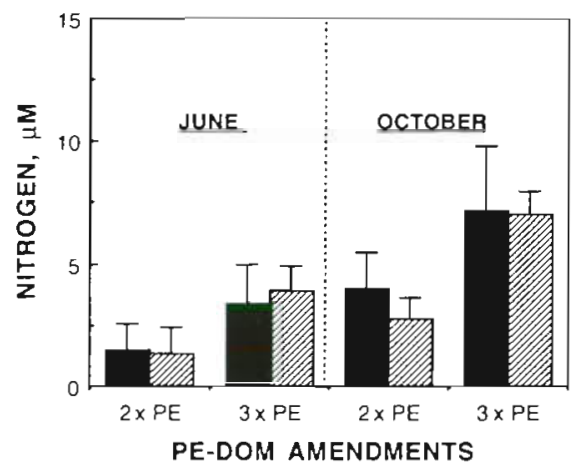

Fig. 2. Net DON utilization (solid bars) and ammonium production (hatched bars) for samples amended with $2 \times \mathrm{PE}$ DOM and $3 \times$ PE-DOM in June and October 1992. Error bars represent \pm 1 SD of duplicate incubations concentration for PE-DOM amended samples were balanced by ammonium production by the bacterial assemblages (Fig. 2)i nitrate and nitrite concentrations remained unchanged throughout the experiment for all treatments (data not shown).

Rates of bacterial carbon production and DOC utilization were greater in samples amended with glucose $+\mathrm{NH}_{4}^{+}\left(0.03 \pm 0.006 \mu \mathrm{M} \mathrm{C} \mathrm{d}^{-1}\right)$ than for samples amended with glucose alone $\left(0.01 \pm 0.001 \mu \mathrm{M} \mathrm{C} \mathrm{d}^{-1}\right.$, Table 1). Ammonium utilization was observed in samples amended with glucose $+\mathrm{NH}_{4}{ }^{+}$The rate of utilization was $-0.65 \pm 0.2 \mu \mathrm{M} \mathrm{NH}_{4}{ }^{+} \mathrm{d}^{-1}$ (data not shown). No DON utilization was detected in samples amended with either glucose $+\mathrm{NH}_{4}{ }^{+}$or glucose.

While initial DOC concentrations for samples amended with $2 \times$ PE-DOM and glucose were comparable (125 and $122 \mu \mathrm{M} C$, respectively), DOC and $\mathrm{O}_{2}$ utilization rates were lower in the glucose amended samples (Table 1). The bacterial carbon production rate for the $2 \times$ PE-DOM amendment $\left(0.20 \pm 0.02 \mu \mathrm{M} \mathrm{C} \mathrm{d}{ }^{-1}\right)$ was significantly greater ( $F$-test, $\alpha=0.05$; Sokal \& Rohlf 1969) than that observed for the glucose amended sample $\left(0.01 \pm 0.001 \mu \mathrm{M} \mathrm{C} \mathrm{d}^{-1}\right)$.

Approximately $70 \%$ of the added DFAA in DFAA amended samples was consumed by the end of the $2.9 \mathrm{~d}$ incubation period and the rate of bacterial carbon production was approximately $0.01 \pm 0.002 \mu \mathrm{M} \mathrm{C} \mathrm{d}^{-1}$ (Table 1). This low rate of bacterial carbon production, relative to that observed for samples amended with
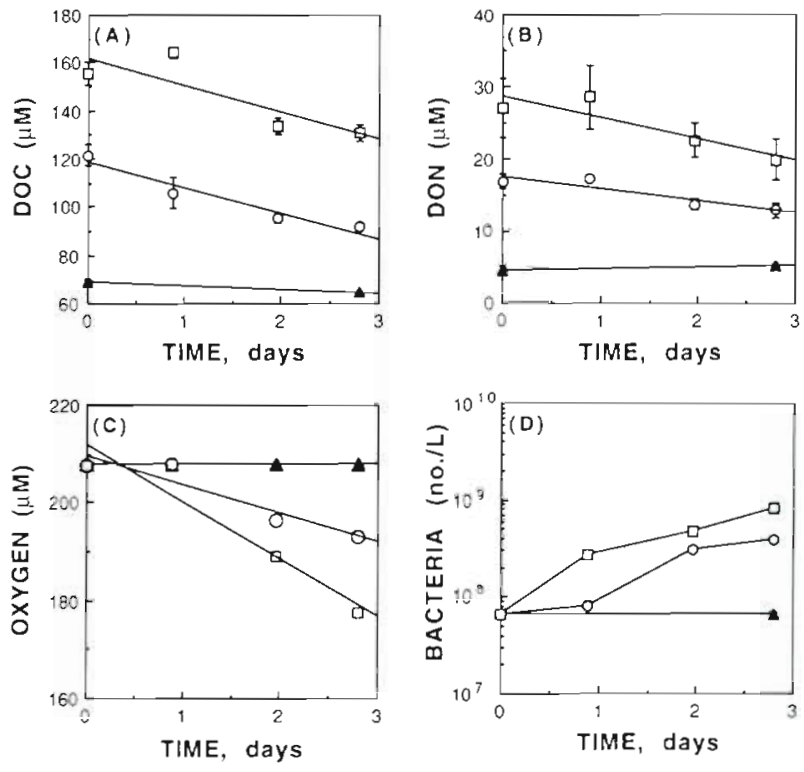

Fig. 3. October 1992. Changes in (A) DOC, (B) DON, (C) oxygen, and (D) bacterial abundances over time for unamended seawater samples (4) and samples amended with plankton extract-DOM $(0,2 \times$ PE-DOM; $\square, 3 \times$ PE-DOM). Error bars represent $\pm 1 \mathrm{SD}$ of duplicate incubations. All lines were derived using linear regression analysis, see text 
PE-DOM, is due to the fact that the added concentration of DOC in the DFAA amended samples was approximately 2 orders of magnitude lower than that of the PE-DOM amendments. In addition, the initial concentration of DFAA $(0.54 \mu \mathrm{M})$ in the DFAA amended samples was below that which would have permitted detection of ammonium production that may have occurred throughout the incubation period.

There was no detectable DON utilization, $\mathrm{O}_{2}$ consumption, or bacterial carbon production detected in the experimental controls for the October experiments (Fig. 3, Table 1). A slight decrease in DOC concentration $\left(1.4 \pm 2.0 \mu \mathrm{M} \mathrm{C} \mathrm{d}^{-1}\right)$ was detected in 1 experimental control (control for PE-DOM incubation series), but this was not significantly different from zero based on the analytical precision. Concentrations of DOC, DON, $\mathrm{O}_{2}$, and bacterial cell numbers remained constant throughout the incubation period for samples individually amended with ammonium, phosphate, and urea.

A second objective of the October incubations was to determine if there were temporal differences in DOM remineralization and biomass production between June and October 1992 for the PE-DOM amended samples and experimental controls. Bacterial carbon production rates for samples amended with PE-DOM appeared greater in June than in October (Table 1). Rates of DOC utilization and oxygen consumption were similar for these treatments at both times of the year. In contrast, DON utilization rates were higher in October than in June (Table 1). In June DON utilization rates were relatively low for both the $2 \times$ and $3 \times$ PE-DOM amended samples $(0.54 \pm 0.7$ and $1.16 \pm$ $0.7 \mu \mathrm{M} \mathrm{N} \mathrm{d}{ }^{-1}$, respectively). In October these rates were higher for the $2 \times$ PE-DOM amendment $(1.56 \pm$ $0.3 \mu \mathrm{M} \mathrm{N} \mathrm{d}^{-1}$ ) and approximately 2 times higher for the $3 \times$ PE-DOM amendment $\left(2.75 \pm 0.7 \mu \mathrm{M} \mathrm{N} \mathrm{d}^{-1}\right)$. Bacterial cells were actively growing in ambient seawater in June $\left(0.05 \pm 0.01 \mu \mathrm{MC}{ }^{1}\right)$, while cell growth was undetectable in October. DOC utilization rates in experimental controls (i.e. ambient in situ DOM concentrations) were slightly greater in June than in October $\left(4.4 \pm 2.6\right.$ and $1.4 \pm 2.0 \mu \mathrm{M} \mathrm{C} \mathrm{d}^{-1}$, respectively).

\section{DISCUSSION}

\section{Bacterial DOM utilization}

The present study sought to evaluate potential bacterial production and DOM turnover in an oligotrophic system using both selected model compounds and labile, recently produced PE-DOM as bacterial substrates. Although the PE-DOM was not characterized beyond the concentrations of its bulk constituents (i.e. DOC and DON), it was assumed to have contained those products associated with zooplankton ingestion (i.e. sloppy feeding) and digestion (i.e. fecal pellet dissolution) as well as other uncharacterized by-products arising from the death and initial decay of the plankton. assemblage.

Of the suite of model compounds tested, only glucose, glucose $+\mathrm{NH}_{4}^{+}$, and DFAA stimulated bacterial activity. The lack of response to $\mathrm{NH}_{4}{ }^{+}$and $\mathrm{PO}_{4}{ }^{3-}$ alone suggests that bacterial populations were not limited by inorganic nitrogen or phosphorus. Rates of DOM utilization, respiration, and bacterial carbon production were highest for samples amended with PE-DOM. Bacterial carbon production rates for PE-DOM amended samples varied between $0.20 \pm 0.02$ and $0.66 \pm 0.14 \mu \mathrm{MC} \mathrm{d}^{-1}$ and were similar to those observed by Kirchman et al. (1991) during a plankton bloom in the North Atlantic $\left(0.12\right.$ to $\left.1.2 \mu \mathrm{M} \mathrm{C} \mathrm{d}{ }^{-1}\right)$. Ambient DOC concentrations reported by Kirchman et al. (1991) during the bloom event ranged between 136 and $196 \mu \mathrm{M} \mathrm{C}$ and were very close to the starting concentrations in our PE-DOM amendments (120 to $175 \mu \mathrm{M} \mathrm{C}$ ). The concentrations of PE-DOM in our incubation experiments were therefore representative of in situ DOM concentrations generated by episodic bloom events.

The disappearance of DON in PE-DOM amended samples was stoichiometrically balanced by regeneration of $\mathrm{NH}_{4}{ }^{+}$, during the exponential growth phase, and an increase of bacterial nitrogen. Utilization of $\mathrm{NH}_{4}^{+}$ was observed only in the sample amended with glucose $+\mathrm{NH}_{4}{ }_{4}$. These findings together with the absence of a bacterial response in samples individually amended with either $\mathrm{NH}_{4}{ }^{+}$or $\mathrm{PO}_{4}{ }^{3-}$ indicate that bacterial populations at Stn $M$ were primarily energy limited (Goldman et al. 1987, Kirchman 1990, Goldman \& Dennett 1991, Ducklow \& Carlson 1992). Because of the energy limitation, however, the cells might also be considered to be nutrient limited in that biomass production appeared to be constrained by the quality (i.e oxidized vs reduced, simple vs complex, inorganic vs organic) of the nutrients available for assimilation. In October the ambient nitrate concentration (ca $12 \mu \mathrm{M}$ ) was more than sufficient to support bacterial nitrogen demands; however, bacterial carbon production was almost 3 times greater in the sample amended with glucose $+\mathrm{NH}_{4}{ }^{+}$than in the sample amended with glucose alone. Dissolved organic nitrogen was the primary nitrogen source supporting bacterial growth for samples amended with PE-DOM even though the ambient concentrations of nitrate in June (ca $5 \mu \mathrm{M}$ ) and October (ca $12 \mu \mathrm{M}$ ) were relatively high. This finding differs from that of Kirchman et al. (1991), who reported that inorganic nitrogen met bacterial nitrogen requirements for natural bacterial assemblages in the North Atlantic. 
The apparent energy limitation of the bacterial populations at Stn M may explain why, in October, bacterial carbon production in glucose amendments $10.01 \pm$ $0.001 \mu \mathrm{M} \mathrm{C} \mathrm{d}^{-1}$ ) was more than an order of magnitude lower than that observed for the $2 \times$ DOM amendment $\left(0.20 \pm 0.02 \mu \mathrm{MC} \mathrm{d}^{-1}\right)$, even though the initial DOC concentrations for both treatments were approximately equal and ambient nitrate concentrations were as high as $1.2 \mu \mathrm{M}$ in both samples. Energy limitation may also explain why, with the exception of the glucose $+\mathrm{NH}_{4}{ }^{+}$amended sample, neither $\mathrm{NH}_{4}{ }^{+}$, urea, nor ambient nitrate were utilized as nitrogen sources in any of the experimental treatments in either June or October

Preferential utilization of DON over ammonium, urea, or nitrate is energetically advantageous since bacteria conserve energy by avoiding biosynthesis of amino acids and other nitrogenous biosynthetic precursors (Payne \& Wiebe 1978). Although urea is an organic nitrogen substrate, it is known to be a poor source of nitrogen for planktonic bacteria since (a) only a limited number of bacteria are capable of hydrolyzing it (Goldman et al. 1987). (b) the energy liberated from its hydrolysis is minimal (Thimann 1963), and (c) its hydrolysis does not yield a 'suitable carbon precursor for building carbon skeletons' (Goldman et al. 1987).

In June, the bacterial carbon production rate for unamended seawater $\left(0.05 \pm 0.01 \mu \mathrm{M} \mathrm{C} \mathrm{d}^{-1}\right)$ was similar to the production rates of 0.018 to $0.044 \mu \mathrm{M} \mathrm{C} \mathrm{d} \mathrm{d}^{-1}$ reported by Hansell et al. (1995) for bacteria growing on unamended seawater in the Sargasso Sea in September. In October, however, no growth was observed in ambient seawater samples at Stn M. We suspect that these temporal variations in bacterial growth in unamended seawater may be related to the significantly higher concentrations of DFAA, dissolved combined amino acids (DCAA), monosaccharides (MCHO), and polysaccharides ( $\mathrm{PCHO}$ ) detected in ambient $85 \mathrm{~m}$ seawater in June compared with October at Stn M (Shultz 1994). Higher ambient concentrations of potentially labile substrates may account for the apparent differences in the physiological status of the bacterial populations at Stn $M$ observed at different times of the year. In June, bacterial cells were actively growing at ambient DOM concentrations, whereas in October their growth appeared to be stationary.

Differences in the physiological state of bacterial populations might also explain observed differences in the rates of bacterial carbon production in PE-DOM amended samples between June and October. Rates of bacterial carbon production were slightly higher in June than in October (Fig. 4A), even though rates of oxygen consumption and DOC utilization were similar at both times of the year (Fig. 4B, C). The energetic costs of growth are considerably higher when cells are coming out of a stationary phase than when actively growing since synthesis of various essential coenzymes, nucleic acids, and other cellular constituents must be initiated before growth and division can proceed (Ducklow \& Carlson 1992, Brock et al. 1994). Bulk DON utilization rates (Fig. 4D) in PE-DOM amendments were greater in October than in June, further supporting our contention that the degree of energy limitation might have been greater in October due to the lower ambient concentrations of DFAA, DCAA, $\mathrm{MCHO}$, and $\mathrm{PCHO}$

\section{Bacterial growth efficiencies}

Where possible, bacterial growth efficiencies were estimated for the various experimental amendments. Growth efficiencies were calculated from rates of (a) bacterial carbon production versus oxygen consumption (gross growth efficiency, GGE); and (b) bacterial carbon production versus DOC utilization (assimilation efficiency, AE). The advantage of estimating bacterial growth efficiencies using these 2 independent parameters (i.e. oxygen consumption and DOC utilization) is that it allows for an intercomparison between DOC consumption relative to how much carbon is actually incorporated into bacterial biomass
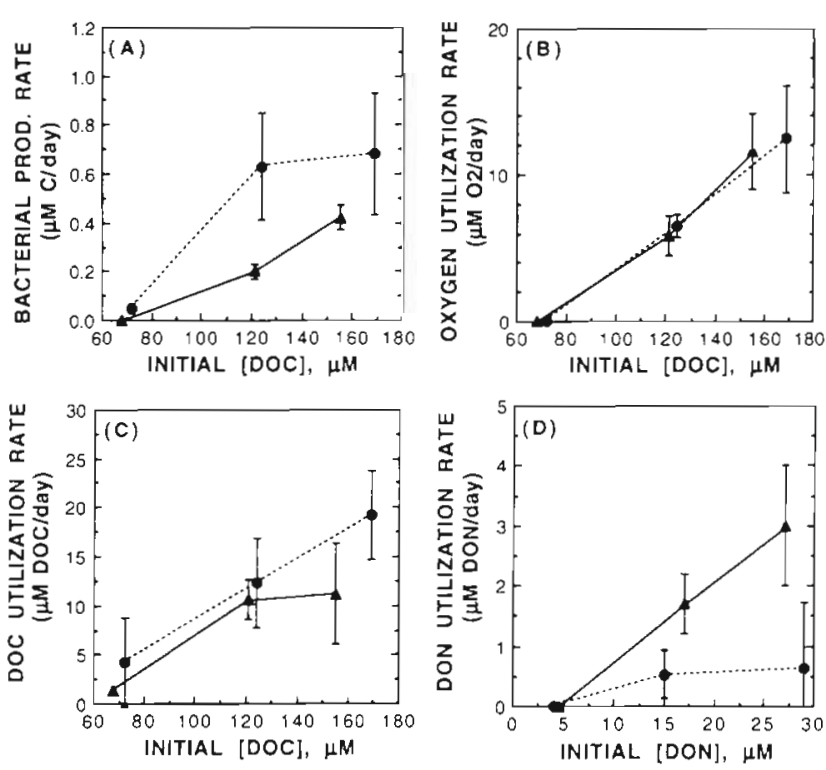

Fig. 4. Rates of (A) bacterial carbon production, (B) oxygen utilization, (C) DOC utilization and (D) DON utilization plotted against the initial DOC or DON concentration for unamended seawater and samples amended with $2 \times$ and $3 \times$ PEDOM for June (o) and October (A) 1992. Rates were calculated by least squares linear regression of each parameter against time for all data points in duplicate incubations (Figs. $1 \& 3$ ). Error bars represent $\pm 1 \mathrm{SE}$ of rate measurements 
versus that respired. In addition, comparison of growth efficiencies estimated by both oxygen consumption (i.e. respiration) and DOC utilization is an initial step in understanding those factors contributing to the variability of conversion efficiency estimates currently cited in the literature (Jahnke \& Craven 1995).

Estimates of GGE and AE are summarized in Table 2 for both June and October, along with the initial DOC: TDN and DOC:DON ratios of the substrates in each experimental treatment. GGE was estimated from rates of bacterial carbon production and oxygen consumption summarized in Table 1 and were calculated as:

$$
\mathrm{GGE}=\mathrm{B}_{\text {rate }} /\left(\mathrm{B}_{\text {rate }}+\mathrm{O}_{2 \text { rate }}\right) \times 100
$$

where $\mathrm{B}_{\text {rate }}$ is the bacterial carbon production rate and $\mathrm{O}_{\text {2rate }}$ is the rate of $\mathrm{O}_{2}$ consumption. Since nitrate and nitrite concentrations remained constant in all experimental treatments, a respiratory quotient $\left(\mathrm{O}_{2}: \mathrm{CO}_{2}\right)$ of 1 was assumed. AE was estimated from rates of bacterial carbon production and DOC utilization summarized in Table 1 and were calculated as:

$$
\mathrm{AE}=\left(\mathrm{B}_{\text {rate }} / \mathrm{DOC}_{\text {rate }}\right) \times 100
$$

where $\mathrm{B}_{\text {rate }}$ is as above and $\mathrm{DOC}_{\text {rate }}$ is the rate of DOC utilization

Estimates of GGE were calculated for samples amended with either PE-DOM, glucose, or glucose+ $\mathrm{NH}_{4}{ }^{+}$since only in these samples were respiration and bacterial carbon production detected. In addition to calculating AE for the PE-DOM, glucose, and glucose+ $\mathrm{NH}_{4}{ }^{+}$amended samples, as was done for estimates of
GGE, we also estimated $A E$ for the June control sample (i.e. unamended ambient seawater) and the October DFA. amended sample since the rates of DOC utilization for these amendments were measurable. The GGE and AE for the glucose amended samples were $0.8 \pm 0.6 \%$ and $0.5 \pm 0.2 \%$, respectively (Table 2 ). The GGE for the sample amended with glucose $+\mathrm{NH}_{4}{ }^{+}$ $(1.9 \pm 0.6 \%)$ was higher than that for the glucose amended sample; however the AE for these 2 amendments were identical $(0.5 \pm 0.1, \%$ and $0.5 \pm 0.2 \%$, respectively). The AE for the the June control sample was $0.6 \pm 0.6 \%$. The October sample amended with DFAA had the highest AE of $9.3 \pm 2.5 \%$ (Table 2), which is consistent with the energetic advantage of bacterial utilization of DFAA as substrates. However, our observed DFAA-based growth efficiency was relatively low compared to the $34 \%$ efficiency observed by Kirchman (1990) for similarly amended samples in the subarctic Pacific. The discrepancy between these 2 DFAA-based growth efficiency estimates is likely due to differences in the physiological states of the bacterial populations. Differences in the physiological states could easily arise from the temporal and spatial variability associated with the systems in which these studies were conducted (i.e. temperate North Pacific vs subarctic Pacific).

GGE for samples amended with PE-DOM ranged from $3.4 \pm 0.9$ to $5.0 \pm 1.7 \%$ and were generally higher in June than in October (Table 2). AE for the PE-DOM amendments were lower than the estimated GGE and ranged from $1.9 \pm 0.3$ to $4.2 \pm 1.2 \%$. Collectively, bac-

Table 2. Gross growth efficiency and assimilation efficiency estimates (see text) for bacterial incubation experiments conducted in June and October 1992. Also presented are dissolved organic carbon to total dissolved nitrogen (DOC:TDN) and DOC to dissolved organic nitrogen (DOC:DON) ratios of the incubations at time $=0$. Standard errors for both GGE and AE estimates were obtained from the propagation of the respective rate standard errors (i.e. in Table 1) through the calculation of GGE and AE

\begin{tabular}{|c|c|c|c|c|c|}
\hline Date & Treatment & $\begin{array}{c}\mathrm{GGE} \\
(\% \pm 1 \mathrm{SE})\end{array}$ & $\begin{array}{c}\mathrm{AE} \\
(\% \pm 1 \mathrm{SE})\end{array}$ & $\begin{array}{c}\text { DOC:TDN } \\
\text { (initial, } \mu M \text { ) }\end{array}$ & $\begin{array}{l}\text { DOC:DON } \\
\text { (initial, } \mu \mathrm{M} \text { ) }\end{array}$ \\
\hline Jun 1992 & $\begin{array}{l}\text { Ambient } \\
2 \times \text { PE-DOM } \\
3 \times \text { PE-DOM }\end{array}$ & $\begin{array}{c}- \\
4.4 \pm 2.5 \\
5.0 \pm 1.7\end{array}$ & $\begin{array}{l}0.6 \pm 0.6 \\
2.4 \pm 1.5 \\
3.4 \pm 1.0\end{array}$ & $\begin{array}{l}7: 1 \\
6: 1 \\
5: 1\end{array}$ & $\begin{array}{r}18: 1 \\
9: 1 \\
6: 1\end{array}$ \\
\hline Oct 1992 & $\begin{array}{l}\text { Ambient } \\
2 \times \text { PE-DOM } \\
3 \times \text { PE-DOM }\end{array}$ & $\begin{array}{c}- \\
3.4 \pm 0.9 \\
3.5 \pm 0.8\end{array}$ & $\begin{array}{c}- \\
1.9 \pm 0.3 \\
4.2 \pm 1.2\end{array}$ & $\begin{array}{l}4: 1 \\
4: 1 \\
4: 1\end{array}$ & $\begin{array}{r}15: 1 \\
7: 1 \\
6: 1\end{array}$ \\
\hline & $\begin{array}{l}\text { Ambient } \\
\mathrm{NH}_{4}{ }^{+} \\
\text {Glucose } \\
\text { Clucose }+\mathrm{NH}_{4}{ }^{+} \\
\text {Urea } \\
\mathrm{PO}_{4}\end{array}$ & $\begin{array}{c}- \\
- \\
0.8 \pm 0.6 \\
1.9 \pm 0.6 \\
- \\
-\end{array}$ & $\begin{array}{c}- \\
- \\
0.5 \pm 0.2 \\
0.5 \pm 0.1 \\
- \\
-\end{array}$ & $\begin{array}{l}3: 1 \\
2: 1 \\
6: 1 \\
4: 1 \\
2: 1 \\
4: 1\end{array}$ & $\begin{array}{r}16: 1 \\
17: 1 \\
25: 1 \\
17: 1 \\
3: 1 \\
16: 1\end{array}$ \\
\hline & $\begin{array}{l}\text { Ambient } \\
\text { DFAA }\end{array}$ & - & $9.3^{-} 2.5^{\text {व }}$ & $\begin{array}{l}3: 1 \\
3: 1\end{array}$ & $\begin{array}{l}16: 1 \\
16: 1\end{array}$ \\
\hline
\end{tabular}
-: estimates not given due to one or more factors not being significantly different from zero 
terial growth efficiencies (both GGE and AE) for all of the PE amended samples (i.e. PE amendments for both June and October) were between 1.9 and $5.0 \%$. These efficiencies are within the range of other estimates of bacterial growth efficiency for bacteria growing on bulk DOM in oligotrophic systems (see, for example, Kirchman et al. 1991, Griffith et al. 1990, and Hansell et al. 1995)

The overall agreement between the estimates of GGE and AE is fairly good and within a factor of 2 . However, bacterial growth efficiencies obtained from both GGE and AE should theoretically be equivalent since the amount of DOC consumed should be balanced by the sum of bacterial carbon production and respiration (i.e. bacterial carbon production + respiration = DOC utilization). There are 2 possible explanations for the differences between the GGE and AE estimates. It is possible that these differences could be attributable to small measurement artifacts associated with one or more of the parameters included in the calculation of GGE or AE. A second explanation for the slightly lower values of $A E$, as compared to those estimated by GGE, could be that there is an uncoupling between DOC utilization and bacterial carbon production and respiration (i.e. bacterial carbon production + respiration $<$ DOC utilization). This uncoupling may be due to uptake and storage of DOC as suggeted by Baxter \& Sieburth (1984) and Carlson \& Ducklow (1995). In some instances, uptake of DOC was almost 2 times greater than the sum of bacterial carbon production and respiration (Table 1). By using a constant biomass conversion factor to determine the rate of bacterial carbon production, any changes in bacterial carbon content that may have occurred due to storage of DOC were not accounted for. If, for example, storage of DOC resulted in a doubling of the bacterial carbon content, it is possible that we may be underestimating bacterial growth efficiency by a factor of 2 . Bacterial growth efficiencies reported here may therefore be considered conservative estimates.

However, even if storage of DOC is taken into account these efficiencies are still substantially lower than the commonly cited $50 \%$ growth efficiency often adopted for marine carbon flux models. The low growth efficiencies reported here could be due to the lower overall growth rates and high maintenance energy requirements of natural bacterial assemblages Gude 1990, Goldman \& Dennett 1991, Ducklow \& Carlson 1992). Growth efficiencies estimated from DOC utilization rates could potentially be lower than estimates derived from respiration rates due to intracellular storage of DOC by the bacterial heterotrophs. Our findings suggest that in oligotrophic surface waters during non-steady state conditions (i.e. episodic bloom events) 90 to $95 \%$ of the DOM consumed by bacteria is remineralized.
The question arises as to what the dominant factors are in controlling the assimilation of DOM into bacterial biomass. This may be best explained by the differences in the C:N ratio of the starting substrate, specifically the substrates' DOC:DON ratio (Table 2 ). Substrates with low $\mathrm{C}: \mathrm{N}$ ratios are enriched in nitrogen and may be more labile and, consequently, may be preferentially utilized and more readily assimilated into bacterial biomass. Conversely, substrates with high C: $N$ ratios may be less labile as a result of the relatively small amounts of nitrogen available for bacterial assimilation and cell synthesis. It has been proposed that, in general, the closer the $\mathrm{C}: \mathrm{N}$ of the substrate is to the average bacterial $C: N$ of 4.5:1 (Goldman et al. 1987), the greater will be the bacterial growth efficiency (Goldman et al. 1987, Kirchman 1990, Goldman \& Dennett 1991, Ducklow \& Carlson 1992, Kroer 1993).

The DOC: TDN ratios of seawater amended with the various substrates used in our experimcnts were generally low and ranged between $7: 1$ (ambient seawater, June 1992) and $2: 1$ (both the $\mathrm{NH}_{4}{ }^{+}$and urea amendments, October 1992). Assuming an average bacterial $C: N$ of $4.5: 1$, it might be expected that significant bacterial production would occur in all amendments, with the highest growth efficiencies occurring in incubations with the lowest DOC:TDN ratios. However, this was not observed across the full range of substrates tested. No bacterial production was observed in either the $\mathrm{NH}_{4}^{+}$or the urea amended incubations (Table 1) which had the lowest $\mathrm{C}: \mathrm{N}$ ratios. Instead, bacterial growth efficiencies were highest for samples amended with either PE-DOM or DFAA, and the relative DOC:TDN ratios in these incubations were either intermediate (i.e. PE-DOM) or quite high (i.e. DFAA). If, rather than comparing the DOC:TDN of the amended seawater, the DOC: DON ratios of the various seawater incubations are considered (Table 2), it is apparent that the form (i.e. inorganic vs organic) of the nitrogen component is a better predictor of the degree of stimulation of bacterial production. With the exception of the DFAA amendment, in which the added concentration of DFAA was too low to alter the DOC:DON of the seawater to which it was added, the highest growth efficiencies were observed for samples with DOC: DON ratios that were less than 10 . Thus, bacterial growth efficiencies appear to be more dependent on the quality of the nitrogen source than on the overall $\mathrm{C}: \mathrm{N}$ ratio of the substrate.

\section{Bacterial turnover of DOC}

An empirical estimate of DOC turnover at Stn M can be calculated using the DOC utilization rates observed in this study together with other known detailed infor- 
mation about bulk DOC at Stn M (Bauer et al. in press, Druffel et al. in press). The concentration of bulk DOC decreases with depth through the main thermocline and the surface DOC is thought to be comprised of both old 'refractory' DOC and younger, more 'labile' DOC (Williams \& Druffel 1987, Bauer et al. 1992, Druffel et al. 1992). Using mass balance calculations of DOC concentrations and natural $\triangle^{14} \mathrm{C}$ of DOC, Druffel et al. (1992) showed that the old DOC is uniformly distributed throughout the water column and that surface waters contain more recent carbon resulting from primary productivity with a component of nuclearweapon-produced ${ }^{14} \mathrm{C}$ (i.e since 1955 ).

Using the Druffel et al. (1982) approach, we conducted a mass balance of the 2 main fractions of DOC (i.e. 'old' and 'young') at $85 \mathrm{~m}$ using DOC concentrations and measured DOC $\Delta^{14} \mathrm{C}$ values for June 1992 at $\mathrm{Stn} \mathrm{M}$. The average DOC concentration at $85 \mathrm{~m}$ is $68 \pm 5 \mu \mathrm{M}$ and in deep waters (i.e. $>1000 \mathrm{~m}$ ) is $39 \pm$ $2 \mu \mathrm{M}$ (Bauer et al. in press). We assume that the old, deep DOC is uniformly distributed throughout the water column and the concentration of 'younger' surface DOC at $85 \mathrm{~m}$ is $29 \pm 5 \mu \mathrm{M}(68 \pm 5 \mu \mathrm{M}$ minus $39 \pm$ $2 \mu \mathrm{M})$. We also assume that the $\Delta^{14} \mathrm{C}$ signature of the 'young' surface DOC is $65 \%$ (equal to surface dissolved inorganic carbon $\Delta^{14} \mathrm{C}$ and suspended particulate organic carbon $\Delta^{14} \mathrm{C}$ values; Druffel et al, in press) and that of the 'old' DOC is $-530 \%$ (Bauer et al. in press). In this way, the estimated value for surface bulk DOC would be:

$(29 \mu \mathrm{M} / 68 \mu \mathrm{M}) \times(65 \%)+(39 \mu \mathrm{M} / 68 \mu \mathrm{M}) \times(-530 \%)=-276 \%$

This value agrees well with the actual measured value of $-290 \pm 5 \%$ (Bauer et al. in press). Thus, to a first approximation, $29 \pm 5 \mu \mathrm{M}$ of surface DOC can be considered young, recently produced material and $39 \pm$ $2 \mu \mathrm{M}$ DOC can be considered old and refractory.

Based on the differences in bacterial DOC utilization rates for unamended $85 \mathrm{~m}$ seawater samples between June and October as well as the high utilization rates observed for PE amended samples, we concur with Carlson \& Ducklow (1995) that the young surface DOC be further divided into 2 sub-fractions: (1) a young labile fraction and (2) a young less labile to refractory fraction. Our schematic representation of these various fractions is illustrated in Fig. 5.

We know from our incubations with the PE-DOM amendments that less than half, i.e. $45 \%(48 \mu \mathrm{M}$ $\left.\mathrm{DOC}_{\text {utilized }} / 106 \mu \mathrm{MDOC}_{\text {added }} \times 100\right)$, of the added DOC was utilized, indicating that a large fraction $(55 \%)$ of the PE-DOM was somewhat refractory or at least not utilized as rapidly. We can infer that, at most, $45 \%$ of the young DOC entering this system via episodic bloom events would be potentially labile. The relatively slow DOC utilization and bacterial production

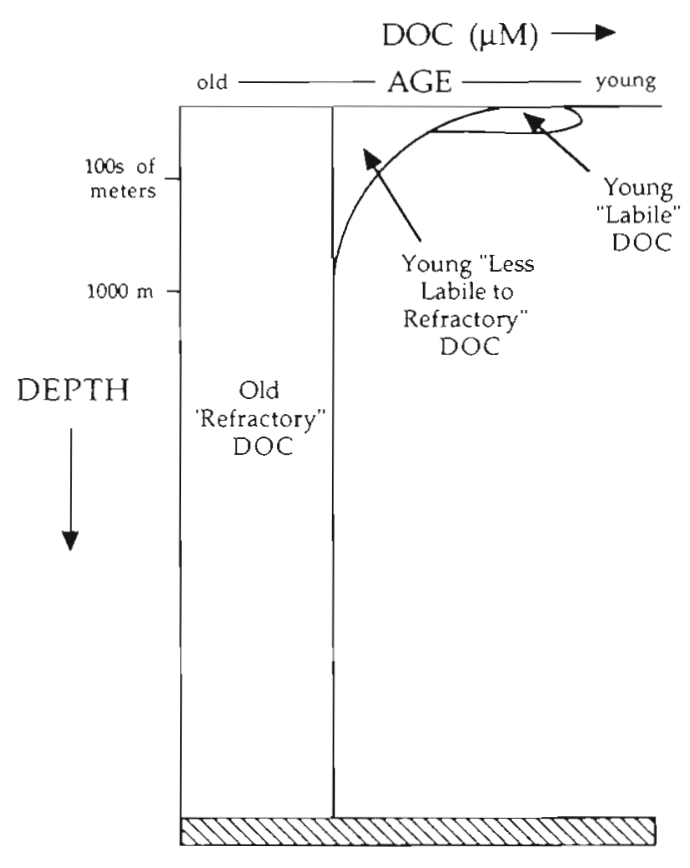

Fig. 5. Conceptual model for the coexistence of various fractions of DOC within the bulk DOC pool (based on Duffel et al. 1992 and Carlson \& Ducklow 1995)

rates observed in June as well as the undetectable rates observed in October (Table 1) for the unamended seawater incubations suggest that most of the young labile fraction in the ambient seawater had already been utilized by the time we sampled in June and nearly completely utilized by October thereby leaving only the less labile to refractory DOC available for utilization.

If we apply this observation to the conceptual model in Fig. 5, then the $29 \mu \mathrm{M}$ young surface DOC, calculated above, would represent the less labile to refractory sub-fraction of the young surface DOC (i.e. $55 \%$ ) which is perhaps utilized on the order of weeks to months to years depending on its degree of refractivity. This suggests that an additional $23 \mu \mathrm{M}$ of young surface DOC would represent the young rapidly utilized labile sub-fraction $\{[29 \mu \mathrm{M} /(1.0-0.45)]-[29 \mu \mathrm{M}]\}$. The total amount of young DOC (both labile and less labile to refractory) entering the system during a bloom event would thus be $52 \mu \mathrm{M}(23+29$, respectively $)$ and the total bulk DOC concentration would then be approximately $120 \mu \mathrm{M}(52 \mu \mathrm{M}$ recently produced DOC + $68 \mu \mathrm{M}$ residual DOC). This estimate is within the range of bulk DOC concentrations observed by others during bloom events (Kirchman et al. 1991, Biddanda et al. 1994). Thus, $120 \mu \mathrm{M}$ is a reasonable estimate of the maximum potential DOC concentration at Stn M during a bloom event.

Assuming then that approximately $23 \mu \mathrm{M}$ DOC $(45 \%$ of $52 \mu \mathrm{M})$ is available for immediate utilization 
and that the DOC utilization rate of labile DOC could range between $12 \mu \mathrm{M} \mathrm{C} \mathrm{d}^{-1}$ (observed in $2 \times \mathrm{PE}$-DOM amendment in June 1992, initial DOC $=120 \mu \mathrm{M}$, see Table 1) to $4.0 \mu \mathrm{M} \mathrm{C} \mathrm{d}^{-1}$ (observed in unamended seawater June 1992, see Table 1), we estimate that the turnover time for labile DOC at Stn $M$ ranges between 2 and $6 \mathrm{~d}\left(23 \mu \mathrm{M} / 12 \mu \mathrm{M} \mathrm{d}^{-1}\right.$ to $23 \mu \mathrm{M} / 4 \mu \mathrm{M}$ $\mathrm{d}^{-1}$, respectively). This estimate of DOC turnover time is similar to that calculated by Kirchman et al. (1991) of approximately 20 to $40 \%$ of the DOC turning over within 3 to $11 \mathrm{~d}$ in a phytoplankton bloom the North Atlantic.

\section{CONCLUSIONS}

The rapid utilization and assimilation of the predominantly zooplankton-derived PE-DOM observed in our experiments supports the contention that the byproducts from secondary production are an important DOM source supporting bacterial production. The zooplankton component of microbial food webs should therefore be included in models of organic carbon flux for oceanic surface waters.

Bacterial growth efficiencies at Stn $M$ in the eastern North Pacific were greatest for samples amended with PE-DOM and DFAA, both of which contained labile, assimilable forms of DON. This finding suggests that the quality of the DOM substrate, specifically the DOC: DON ratio, must be considered when evaluating the lability of a particular substrate and the growth efficiency of native bacterial populations on these substrates. The bacterial populations in surface waters at Stn $M$ appear to be primarily energy limited and the extent of this limitation appears to vary temporally. Bacterial growth efficiencies reported here are considerably lower than the $50 \%$ growth efficiency commonly used for calculations of marine carbon budgets, indicating that lower values should be appljed for open ocean systems. Based on DOC utilization rate measurements from this study together with independent geochemical estimates of bulk DOC turnover, we estimate that turnover times for the labile fraction of the bulk DOC at Stn M range from 2 to $6 \mathrm{~d}$.

Acknowledgements. We thank K. Smith for his encouragement and allowing us to participate on the Pulse cruises, $S$. Griffin, W. Tai, D. Wolgast for their help in sampling and sample processing, and the captain and crew of the RV 'New Horizon' for logistical help. The authors also thank Drs J Chanton, R. Coffin, and L. Proctor for their insightful reviews of this manuscript. This work was supported by National Science Foundation grants OCE-9101540 and OCE-9501531 (to J.E B.) and OCE-9101183 and OCE-9417391 (to E.R.M.D.).

\section{LITERATURE CITED}

Amon RMW, Benner R (1994) Rapid cycling of high-molecular-weight dissolved organic matter in the ocean. Nature 369:549-552

Azam F, Ammerman JW (1984) Cycling of organic matter by bacterioplankton in pelagic marine ecosystems: microenvironmental considerations. In: Fasham MRJ (ed) Flows of energy and materials in marne ecosystems: theory and practice. Plenum Publishing Corp, New York, p 345-359

Azam $F$, Fenchel $T$, Field JG, Gray JS, Meyer-Reil LA, Thingstad F (1983) The ecological role of water-column microbes in the sea. Mar Ecol Prog Ser 10:257-263

Barber RT (1968) Dissolved organic carbon from deep waters resists microbial oxidation. Nature 220:274-275

Bauer JE, Druffel ERM, Williams PM, Wolgast, D, Griffin S (in press) Time dependent variations in the natural radiocarbon content of dissolved organic matter in the eastern north Pacific Ocean. J Geophys Res

Bauer JE, Occelli ML, Williams PM, McCaslin PC (1.993) Heterogenous catalyst structure and function: review and implications for the analysis of dissolved organic carbon and nitrogen in natural waters. Mar Chem 41:75-89

Bauer JE, Williams PM, Druffel ERM (1992a) ${ }^{14} \mathrm{C}$ activity of dissolved organic carbon fractions in the central. North Pacific and Sargasso Sea. Nature 357:667-670

Baxter M, Sieburth JM (1984) Metabolic and ultrastructural response to glucose of two eutrophic bacterid isolated from seawater at different enriching concentrations. Appl Environ Microbiol 47:31-38

Biddanda B, Opsahl S, Benner R (1994) Plankton respiration and carbon flux through bacterioplankton. Limnol Oceanogr 39:1259-1275

Braman RS, Hendnx SA (1989) Nanogram nitrite and nitrate determination in environmental and biological matenals by vanadium (III) reduction with chemlluminescence detection. Anal Chem 61:2715-2718

Brock TD, Madigan MT, Martinko JM, Parker J (1994) Biology of microorganisms. Prentuce Hall, Englewood Cliffs, NJ

Burney CM (1986) Bacterial utilization of total in situ dissolved carbohydrate in offshore waters. Limnol Oceanogr 31:427-431

Carlson CA, Ducklow HW (1995) Dissolved organic carbon in the upper ocean of the central Equatonal Pacific. 1992: daily fine scale vertical variations. Deep Sea Res II 42:639-656

Carlson CA, Ducklow HW (1996) Growth of bacterioplankton and consumption of dissolved organic carbon in the oligotrophic Sargasso Sea. Aquat Microb Ecol 10:69-85

Coffin RB, Connolly JP, Harris PS (1993) Availability of dissolved organic carbon to bacterioplankton examined by oxygen utilization. Mar Erol Prog Ser 101:9-22

Cole JJ, Findley S, Pace ML (1988) Bacterial production in fresh and saltwater ecosystems: a cross-system overview. Mar Ecol Prog Ser 43:1-10

Druffel ERM, Bauer JE, Willams PM, Griffin S, Wolgast D (in press) Seasonal variabilty of partıculate organic radiocarbon in the northeast Pacific Occan. J Geophys Res

Druffel ERM, Williams PM, Bauer JE, Ertel JR (1992) Cycling of dissolved and particulate organic matter in the open ocean. J Geophys Res 97:15639-15659

Ducklow HW, Carlson CA (1992) Oceanic bacterial production. Adv Microb Ecol 12:113-181

Eppley RW, Swift E, Redalje DG, Landry MR, Haas LW (1988) Subsurface chlorophyll maximum in August-September 1985 in the CLIMAX area of the North Pacific. Mar Ecol Prog Ser 42:289-301 
Fasham MJ (1984) Flows of energy and materials in marine ecosystems: theory and practice. Plenum Press, New York

Garside C (1982) A chemiluminescent technique for the determination of nanomolar concentrations of nitrite and nitrate in seawater. Mar Chem 11:159-167

Goldman JC, Caron DA, Dennett MR (1987) Regulation of gross growth efficiency and ammonium regeneration in bacteria by substrate $\mathrm{C}: \mathrm{N}$ ratio. Limnol Oceanogr 32 : $1239-1252$

Goldman JC, Dennett MR (1991) Ammonium regeneration and carbon utilization by marine bacteria grown on mixed substrates. Mar Biol 109:369- 378

Griffith PC, Douglas DJ, Wanwright SC (1990) Metabolıc activity of size-fractionated plankton in estuarine, nearshore, and continental shelf waters of Georgia. Mar Ecol Prog Ser 59:263-270

Gude $H$ (1990) Bacterial net production approaching zero - a frequent phenomenon in pelagic environments. Arch Hydrobiol Beih Ergebn Limnol 34:165-169

Hansell DA, Bates NR, Gunderson K (1995) Mineralization of dissolved organic carbon in the Sargasso Sea. Mar Chem 51:201-212

Hedges JI (1992) Global biogeochemical cycles: progress and problems. Mar Chem 39:63-96

Hill DW, Walters FH, Wilson TD, Stuart JD (1979) High performance liquid chromatographic determination of amino acids in the picomole range. Anal Chem 51:1338-1341

Jahnke RA, Craven DB (1995) Quantifying the role of heterotrophic bacteria in the carbon cycle: a need for respiration rate measurements. Limnol Oceanogr 40:436-441

Jumars PA, Penry DL, Baross JA, Perry MJ, Frost BW (1989) Closing the microbial loop: dissolved carbon pathway to heterotrophic bacteria from incomplete ingestion, digestion and absorption in animals. Deep Sea Res 36:483-495

Keil RG, Kirchman DL (1991) Contribution of dissolved free amino acids and ammonium to the nitrogen requirements of heterotrophic bacterioplankton. Mar Ecol Prog Ser 73: $1-10$

Keil RG, Kirchman DL (1994) Abiotic transformation of labile protein to refractory protein in sea water. Mar Chem 45: $187-196$

Keys A, Christensen EH, Krogh A (1935) The organic metabolism of seawater with special reference to the ultimate food cycle in the sea. J Mar Biol Ass UK 20:181-196

Kirchman DL (1990) Limitation of bacterial growth by dissolved organic matter in the subarctic Pacific. Mar Ecol Prog Ser 62:47-54

Kirchman DL, Suzuki Y, Garside C, Ducklow HW (1991) High organic turnover rates of dissolved organic carbon during a spring phytoplankton bloom. Nature 352:612-614

Kroer N (1993) Bacterial growth efficiency on natural dissolved organic matter. Limnol Oceanogr 38:1282-1290

Lee S, Fuhrman JA (1987) Relationships between biovolume and biomass of naturally derived marine bacterioplankton. Appl Environ Microbiol 53:1298-1303

Lindroth P, Mopper K (1979) High performance liquid chromatographic determination of subpicomole amounts of amino acids by pre-column fluorescence derivatization

This article was submitted to the editor with o-phthaldialdehyde. Anal Chem 51:1667-1674

Meyers JL, Edwards RT, Risely R (1987) Bacterial growth on dissolved organic carbon from a blackwater river. Microb Ecol 13:13-29

Michaelson J, Zhang X, Smith RC (1988) Variability of pigment biomass in the California Current system as determined by satellite imagery. 2 . Temporal variability. J Geophys Res 93:10883-10896

Ogura N (1972) Rate and extent of decomposition of dissolved organic matter in surface seawater. Mar Brol 13:89-93

Payne WJ, Wiebe WJ (1978) Growth yield and efficiency in chemosynthetic microorganisms. A. Rev Microbiol 32: $155-183$

Peterson BJ (1984). Synthesis of carbon stocks and flows in the open ocean mixed layer. In: Hobbie JE, Williams PJ LeB (eds) Heterotrophic activity in the sea. Plenum Press, New York, p 547-554

Pomeroy LR, Wiebe WJ (1993) Energy sources for microbial food webs. Mar Microb Food Webs 7:101-118

Porter KG, Feig YS (1980) The use of DAPI for identifying and counting aquatic microflora. Limnol Oceanogr 25:948-951

Rakestraw NW (1947) Oxygen consumption in sea water over long periods. J Mar Res 6:259-263

Shultz GE (1994) Distributions of dissolved and particulate amino acids and carbohydrates in the eastern North Pacific Ocean. MSc thesis, Florida State University, Tallahassee

Sieracki ME, Sieburth JMCN (1985) Factors controlling the periodic fluctuation in total planktonic bacterial populations in the upper ocean: comparison of nutrient, sunlight and predation effects. Mar Microb Food Webs 1:35-50

Smith KL, Baldwin RJ, Williams PM (1992) Reconciling particulate organic carbon flux and sediment community oxy. gen consumption in the deep North Pacific. Nature 359: $313-316$

Smith RC, Zhang X, Michaelson J (1988) Variability of pigment biomass in the California Current sistem as determined by satellite imagery. J Geophys Res 93: $10863-10882$

Sokal RR, Rohlf FJ (1969) Introduction to biostatistics. WH Freeman and Company, San Francisco

Solorzano L (1969) Determination of ammonia in natural waters by the phenolhypochlorite method. Limnol Oceanogr 14:799-801

Thimann KV (1963) The life of Bacteria, 2nd edn. Macmillan Press, New York

Wheeler PA, Kirchman DL (1986) Utilization of inorganic and organic nitrogen by bacteria in marine systems. Limnol Oceanogr 31:998-1009

Williams PM, Bauer JE, Robertson KJ, Wolgast DM, Occelli M (1993) Report on DOC and DON measurements made at Scripps Institution of Oceanography, 1988-1991 Mar Chem 41:271-281

Williams PM, Carlucci AF (1976) Bacterial utilization of organic matter in the deep sea. Nature 262:810-811

Williams PM, Druffel ERM (1987) Radiocarbon in dissolved organic matter in the central North Pacific ocean. Nature, $330: 246-248$

Manuscript first recelved: August 15, 1995

Revised version accepted: March 18, 1996 